\title{
The Tropical Forest and Fire Emissions Experiment: method evaluation of volatile organic compound emissions measured by PTR-MS, FTIR, and GC from tropical biomass burning
}

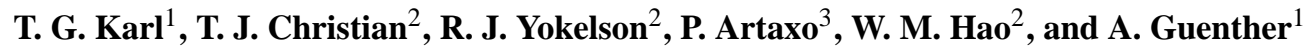 \\ ${ }^{1}$ National Center for Atmospheric Research, Boulder, USA \\ ${ }^{2}$ University of Montana, Department of Chemistry, Missoula, USA \\ ${ }^{3}$ University of Sao Paulo, Department of Physics, Sao Paulo, Brazil \\ Received: 7 May 2007 - Published in Atmos. Chem. Phys. Discuss.: 25 June 2007 \\ Revised: 29 August 2007 - Accepted: 13 November 2007 - Published: 28 November 2007
}

\begin{abstract}
Volatile Organic Compound (VOC) emissions from fires in tropical forest fuels were quantified using Proton-Transfer-Reaction Mass Spectrometry (PTRMS), Fourier Transform Infrared Spectroscopy (FTIR) and gas chromatography (GC) coupled to PTRMS (GC-PTR-MS). We investigated VOC emissions from 19 controlled laboratory fires at the USFS (United States Forest Service) Fire Sciences Laboratory and 16 fires during an intensive airborne field campaign during the peak of the burning season in Brazil in 2004. The VOC emissions were dominated by oxygenated VOCs (OVOC) (OVOC/NMHC 4:1, NMHC: nonmethane hydrocarbons) The specificity of the PTR-MS instrument, which measures the mass to charge ratio of VOCs ionized by $\mathrm{H}_{3} \mathrm{O}^{+}$ions, was validated by gas chromatography and by intercomparing in-situ measurements with those obtained from an open path FTIR instrument. Emission ratios for methyl vinyl ketone, methacrolein, crotonaldehyde, acrylonitrile and pyrrole were measured in the field for the first time. Our measurements show a higher contribution of OVOCs than previously assumed for modeling purposes. Comparison of fresh ( $<15 \mathrm{~min})$ and aged ( $>1 \mathrm{~h}-1 \mathrm{~d})$ smoke suggests altered emission ratios due to gas phase chemistry for acetone but not for acetaldehyde and methanol. Emission ratios for numerous, important, reactive VOCs with respect to acetonitrile (a biomass burning tracer) are presented.
\end{abstract}

\section{Introduction}

It is widely recognized that emissions of volatile organic compounds (VOC) from biomass burning can add significant quantities of reactive species to the atmosphere, altering its

Correspondence to: T. Karl

(tomkarl@ucar.edu) chemistry on a global scale (Crutzen et al., 1990). In recent years it also became clear that global budgets of oxygenated VOCs (OVOC) are particularly uncertain (Singh et al., 2004) and that a substantial amount of these species can be released from burning vegetation (Yokelson et al., 2003a). Many of these compounds have important implications for modeling the chemistry in the atmosphere. For example light carbonyls such as formaldehyde and acetone can influence the HOx budget in the upper troposphere (Mckeen et al., 1997). Acetone and acetaldehyde can also be converted to acetyl peroxy radicals by atmospheric oxidation and lead to formation of PAN (peroxyacetic nitric anhydride) type compounds, which act as relatively long-lived reservoirs for nitrogen oxides (NOx) (Roberts et al., 1998). Long range transport of these compounds can subsequently release reactive nitrogen back to the atmosphere and change ozone production rates in remote regions.

Measurements of primary VOC emissions from fires are needed to accurately initialize photochemical models that assess the local to global effects of smoke. VOC concentrations measurements in biomass burning plumes are also needed to assess our understanding of photochemical oxidation in smoke plumes (Goode et al., 2000; Hobbs et al., 2003). Measurements show that a wide suite of oxygenated compounds can be released from fires (Friedli et al., 2001; Koppmann et al., 1997; Christian et al., 2003). Many of these compounds are still poorly quantified due to analytical challenges and their relative contributions to the total VOC component of biomass burning emissions are poorly known. Early studies of biomass burning carried out in the laboratory (Lobert et al., 1990), or in important fire ecosystems in the field, concentrated on measuring fire emissions of $\mathrm{CO}_{2}, \mathrm{CO}, \mathrm{NO}_{x}$, and hydrocarbons (e.g. savannas - SAFARI 92 (Blake et al., 1996); tropical forest - SCAR-B (Ferek et al., 1998). Later

Published by Copernicus Publications on behalf of the European Geosciences Union. 


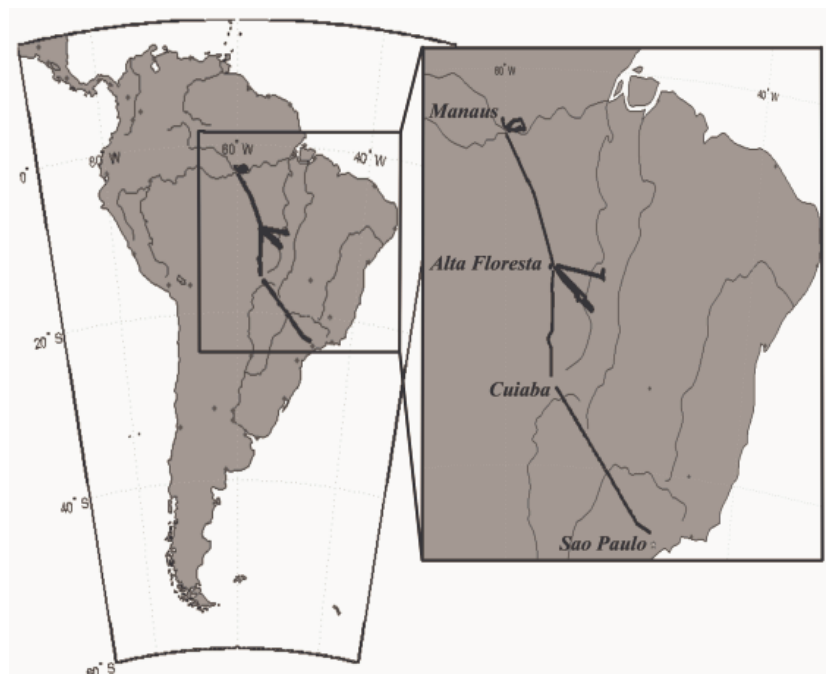

Fig. 1. Research Flights and study area during TROFFEE in 2004.

laboratory work showed that $60-80 \%$ of the organic emissions from fires were typically reactive OVOC (Yokelson et al., 1996; Holzinger et al., 1999) The dominance of OVOC was then confirmed in field and lab work for most of the major types of biomass burning: e.g. savannas, agricultural waste, and peat (Christian et al., 2003; Sinha et al., 2003); biofuel (Bertschi et al., 2003); and boreal forest (Goode et al., 2000). These OVOC emissions were also shown to play a critical role in smoke chemistry (Mason et al., 2001; Jost et al., 2003; Trentmann et al., 2005). However, there were no data on OVOC emissions from tropical deforestation fires despite this consistently being estimated as one of the 3 largest global types of burning (Crutzen et al., 1990; Andreae et al., 2001b).

The TROFFEE (Tropcial Fire and Forest Emissions Experiment) campaign was designed to address the lack of OVOC information for tropical deforestation fires. Brazil was a logical choice for this effort since it has the most tropical forest and deforestation fires. In addition, a good knowledge base on many aspects of Brazilian fires was in place (Crutzen et al., 1985, Andreae et al., 1988; Kaufman et al., 1998; Ferek et al., 1998; Carvalho et al., 2001). The intensive part of the TROFFEE field campaign was carried out in 3 Amazonian states of Brazil (Mato Grosso, Pará, and Amazonas) from 27 August-8 September 2004. This probed the spatial and temporal peak of global deforestation fires for 2004. The airborne portion of the field campaign featured the characterization of 16 nascent lofted biomass burning plumes and regional haze by Proton-Transfer-Reaction mass spectrometry (PTR-MS), airborne Fourier Transform Infrared Radiation spectrometry (AFTIR), whole air sampling into stainless steel canisters, and $\mathrm{O}_{3}$ and particle measurements. This instrument package was particularly well suited for measuring OVOC and other major fire emissions such as $\mathrm{CO}_{2}, \mathrm{CO}, \mathrm{CH}_{4}, \mathrm{NO}_{\mathrm{x}}$, and hydrocarbons. A groundbased field campaign featured chemical characterization of typical regional unlofted biomass burning plumes by FTIR as well as fuel consumption and fire ecology measurements on a planned research fire. Prior to the field campaign, a laboratory experiment co-deployed and intercompared PTR-MS, open-path FTIR, and GC-PTR-MS on 32 controlled fires that burned 19 tropical fuels, which are reported here. The laboratory experiment was carried out to validate PTR-MS results obtained in smoke, help plan the PTR-MS sampling protocol for the field campaign, and (due to the higher smoke concentrations sampled) quantify emissions that went unmeasured in the field.

In this paper, we concentrate on a detailed presentation of the validation of the PTR-MS results in smoke, and quantify the relative contributions of various species on the PTR-MS mass spectra. These insights are gleaned from coupling with the FTIR and GC-PTR-MS results. In addition, we note that acetonitrile is now recognized as a useful tracer for biomass burning and that the capability for accurate acetonitrile measurements by PTR-MS is becoming widespread (De Gouw et al., 2006a; Holzinger et al., 1999). Thus, we also present the ratios for numerous, reactive VOC to acetonitrile as measured by PTR-MS in both the lab and the field and for both fresh and moderately aged smoke. Related papers present fire and fuel specific emission factors on a $\mathrm{g} / \mathrm{kg}$ basis for the lab fires (Christian et al., 2007a $\mathrm{a}^{1}$ ), airborne sampling (Yokelson et al., 2007), and the ground-based field sampling (Christian et al., 2007b ${ }^{2}$.

\section{Methods}

\subsection{Missoula burning facility}

The combustion facility at fire science laboratory, (described in more detail by Christian et al., 2003) measures $12.5 \mathrm{~m} \times 12.5 \mathrm{~m} \times 22 \mathrm{~m}$ high. A $1.6 \mathrm{~m}$ diameter exhaust stack with a $3.6 \mathrm{~m}$, inverted funnel opening extends from $\sim 2 \mathrm{~m}$ above the floor to the ceiling. The room is pressurized with outside air that has been conditioned for temperature and relative humidity $(\mathrm{RH})$, and is then vented through the stack, completely entraining the emissions from fires burning beneath the funnel. A sampling platform surrounds the stack at

\footnotetext{
${ }^{1}$ Christian, T. J., Karl, T., Yokelson, R. J., Guenther, A., and Hao, W. M.: The Tropical Forest and Fire Emissions Experiment: Comprehensive laboratory measurements of the emissions from burning sugar cane, palms, and other tropical fuels, Atmos. Chem. Phys. Discuss., submitted, 2007a.

${ }^{2}$ Christian, T. J., Yokelson, R. J., Carvalho, A., Griffith, D. W. T., Alvarado, E. C., Santos, J. C., Neto, T. G. S., Veras, C. A. G., and Hao, W. M.: The Tropical Forest and Fire Emissions Experiment, in : Trace gases emitted by smoldering logs and dung on deforestation and pasture fires in Brazil, Atmos. Chem. Phys. Discuss., 2007, submitted, 2007b.
} 
$17 \mathrm{~m}$ elevation where all the temperature, pressure, trace gas, and particle measurement equipment for this experiment was deployed except the instrument for background $\mathrm{CO}_{2}$ (LICOR 6262). The fuel bed was a metal tray $(\sim 50 \times 50 \mathrm{~cm})$ covered by an inert heat shield and a layer of sand. The bed was continuously weighed by an electronic balance. During these experiments, chamber temperature and $\mathrm{RH}$ averaged $20.4^{\circ} \pm 3^{\circ} \mathrm{C}$ and $40.4 \% \pm 7.1 \%$. Smoke temperature and $\mathrm{RH}$, at platform level, varied throughout each fire and from fire to fire. The maximum smoke temperature observed was $43^{\circ} \mathrm{C}$. A total of 19 tropical fires were sampled at the USFS Fire laboratory consisting of a mix of tropical plant species (Artocarpus altilus, Calliandra haematocephala, Theobroma cacao, Davidson pruriens, Eucalyptus sp., Ficus, Mango, Neraudia sp., Psidium cattleianum, Sugar cane, Cecropia sp., Sparmannia sp., Munroidendron racemosum, Erythrina humeana, Terminalia catappa and Dambo).

\subsection{Flight operations}

The TROFFEE airborne campaign consisted of 44.5 flight hours between 27 August and 8 September 2004 on an Embraer 110B belonging to the Brazilian National Institute for Space Research (Instituto Nacional de Pesquisas Espaciais (INPE)). The aircraft was primarily based in Alta Floresta, Mato Grosso in the southern Amazon $\left(-9.917^{\circ},-56.017^{\circ}\right)$, and in Manaus, Amazonas. Regional haze due to biomassburning and the nascent emissions from sixteen fires (primarily deforestation fires associated with expansion of mechanized agriculture) were sampled in the states of Mato Grosso and Pará within about one-hour flight time $(\sim 300 \mathrm{~km})$ of Alta Floresta. Three agricultural fires were sampled near Manaus. Biogenic VOC emissions were also characterized on these flight legs above pristine tropical rain forest and plantations and are described elsewhere (Yokelson et al., 2007).

Figure 1 shows flight tracks flown onboard the research aircraft. The biomass burning flight operations were typically planned according to local weather and fire forecasts. One important aspect of the fire sampling strategy for all fires was to measure the smoke composition as close as possible to the source. In the past measurements in the immediate vicinity of a fire were rarely conducted (Andreae et al., 2001a) and plumes were often sampled at certain distances downwind of a fire, where VOC patterns have already changed due to aging and photochemical processing (Trentmann et al., 2005). Plume penetrations were typically flown between 100 and $2000 \mathrm{~m}$ above the fire. Nearly all the fires we found in Mato Grosso and southern Para were related to the expansion of existing, large farms or ranches located on the edge of forested (or partially forested) areas that were adjacent to large tracts of cleared, often cultivated land. More detailed information on specific fires can be found in Yokelson et al. (2007). The investigation of aging of individual plumes proved to be challenging due to concentrated regional haze on all days and or the mixing of plumes from different fires.
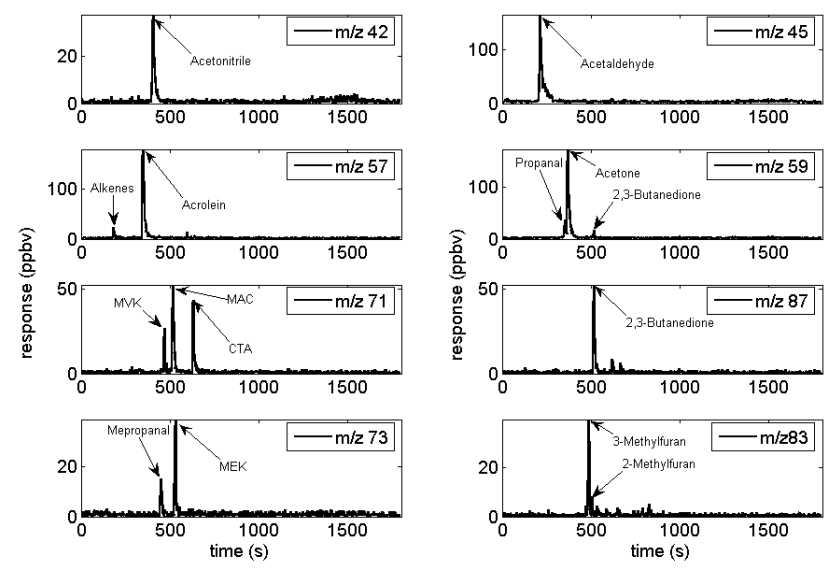

Fig. 2. GC-PTRMS chromatograms for eight mass channels $(\mathrm{m} / \mathrm{z})$. (MVK: methyl-vinylketone, MAC: methacrolein, CTA: Crotonaldehyde, MePropanal : Methylpropanal).

\subsection{PTRMS}

PTR-MS has been described in detail elsewhere (Lindinger et al., 1998). Briefly, PTR-MS combines chemical ionization (CI) due to ion-molecule-reactions with the swarm technique of the flow-drift-tube type. $\mathrm{H}_{3} \mathrm{O}^{+}$is used as the ionizing agent and ionization occurs when VOC trace constituents in the air have a higher proton affinity (PA) than that of $\mathrm{H}_{2} \mathrm{O}$. The flow-drift-tube system guarantees that the reactions take place under well defined conditions so that the count rates of product ions can be quantitatively connected to the absolute concentrations of the VOCs under investigation for exothermic reactions:

$[\mathrm{VOC}]=\mathrm{CF} \cdot \frac{\operatorname{cps}\left(\mathrm{VOC}^{+}\right)}{\operatorname{cps}\left(\mathrm{H}_{3} \mathrm{O}^{+}\right)}$

with CF representing the calibration factor, which can also be calculated based on the proton transfer rate constants $\mathrm{k}$ (e.g. Gouw and Warneke, 2007). Proton transfer rate constants are typically large, corresponding to the collisional limiting values $\left(\approx 10^{-9} \mathrm{~cm}^{3} / \mathrm{s}\right)$ (Lindinger et al., 2001). The value for $E / N$ ( $E$ being the electric field strength and $N$ the buffer gas density) in the drift tube is kept high enough ( $\sim 120$ Townsend) to avoid strong clustering of $\mathrm{H}_{3} \mathrm{O}^{+}$ions with water. The drift tube temperature was temperature controlled at $40^{\circ} \mathrm{C}$. The sensitivity of the PTR-MS instrument during the TROFFEE field study was typically on the order of $\sim 70 \mathrm{~Hz} / \mathrm{ppbv}$ (counts per second per ppbv) for acetone and $50 \mathrm{~Hz} / \mathrm{ppbv}$ for methanol at $2.0 \mathrm{mbar}$ buffer gas pressure with a reaction time of $110 \mu \mathrm{s}$ and $4 \mathrm{MHz} \mathrm{H}_{3} \mathrm{O}^{+}$ions. The detection limit $(D L)$ for compounds investigated in this work was inferred from a signal to noise ratio $(S / N)$ of 2 according to $D L=2 \times S D_{\text {blank }} /$ sensitivity, with $S D_{\text {blank }}$ being the standard deviation of background count rates. For a $5 \mathrm{~s}(2 \mathrm{~s})$ integration time this resulted in theoretical detection limits around $\sim 20$ pptv ( $\sim 58 \mathrm{pptv})$. Here we assign a default reaction rate 


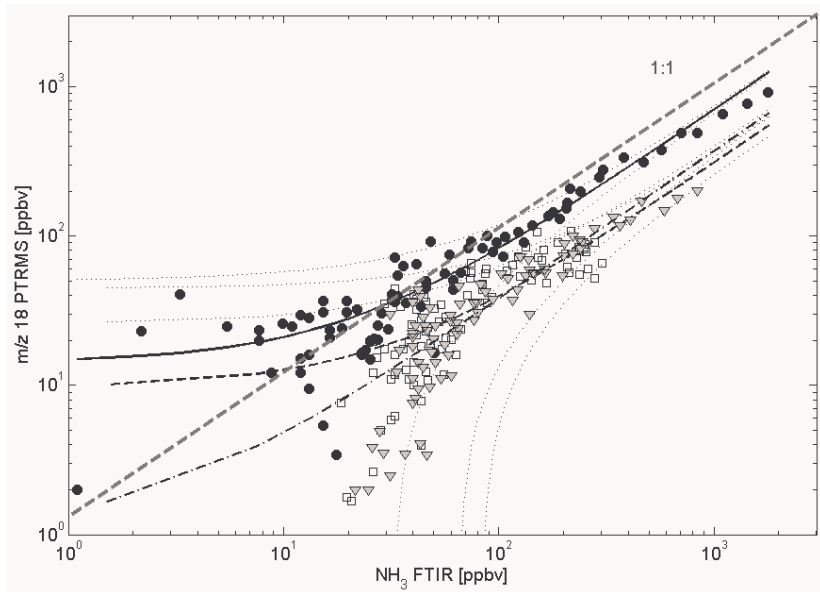

Fig. 3. Ammonia intercomparison plots for 3 laboratory fires: Fire 1 (Tropical composite, circles), fire 2 (Cacao, triangles) and fire 3 (Terminalia catappa, square symbols) yielded slopes of $0.69 \pm 0.04$ (R-square: 0.9880$), 0.30 \pm 0.06$ (R-square: 0.64 ) and $0.37 \pm 0.05$ (Rsquare: 0.9197), respectively. Thin dotted lines indicate the $95 \%$ confidence interval for each regression. Solid black (fire 1), dashed black (fire2) and dashed dotted black (fire 3) lines represent the fit lines. For comparison the 1:1 line (gray dashed line) is also plotted.

constant of $2.2 \times 10^{-9} \mathrm{~cm}^{3} / \mathrm{s}$ when the concentration measurement is based on (1) with an estimated uncertainty on the order of $\pm 30 \%$. In addition we used a gravimetrically prepared multi component standards to calibrate the PTR-MS instrument for methanol, acetonitrile, acetone, acetaldehyde, benzene, toluene, xylenes, 1,3,5 trimethylbenzene, hexanal, 2-pentanone, isoprene and MVK with an estimated uncertainty of $\pm 20 \%$. Acetic acid was measured using a gravimetrically prepared liquid standard. Fragmentation patterns for all VOCs investigated in this study were measured using pure (>98\%) standards purchased from Sigma-Aldrich. Due to the low proton affinity of formaldehyde $(\mathrm{PA}=170.4 \mathrm{kcal} / \mathrm{mol})$ and $\mathrm{HCN}$ the backward reaction via $\mathrm{H}_{2} \mathrm{O}$ can become significant and thus lower the sensitivity for these compounds as indicated by Hansel et al. (1997). We inferred empirical calibration factors for these compounds as a function of humidity by intercomparing with a Fourier transform infrared radiation spectrometer (FTIR). The PTRMS inlet for aircraft operations consisted of a $5 \mathrm{~m}$ PFA-Teflon line (o.d. 1/4 inch, backward facing inlet at the aircraft fuselage) pumped by a diaphragm pump (Pfeiffer, MD4). At its end a pressure controlled Teflon line (o.d. $0.0625 \mathrm{inch}$, length $0.2 \mathrm{~m}$ ) led $\sim 100 \mathrm{sccm}$ of this air stream to a second bypass where a critical orifice at the drift tube maintained a flow of $\sim 15 \mathrm{sccm}$ into the PTRMS instrument. The pressure in the $5 \mathrm{~m}$ PFAline was reduced to $500 \mathrm{mbar}$ in order to avoid condensation, minimize memory effects and assure a fast response time. The overall response time caused a delay time of less than $2 \mathrm{~s}$, measured by spiking an acetone and isoprene concentration pulse at the inlet.

\subsection{GC-PTRMS}

As the PTR-MS method gives only information on $\mathrm{m} / \mathrm{z}$ data for VOCs, it is not always possible to unambiguously identify released VOCs. For the laboratory experiments, we coupled a GC column to the PTR-MS instrument. Similar setups have been used in the past (Lindinger et al., 2001; Warneke et al., 2003a). The effluent gas stream from the smoke stack was trapped on Tenax for $10 \mathrm{~min}$ at $-10^{\circ} \mathrm{C}$ and subsequently desorbed by heating the trap up to $200^{\circ} \mathrm{C}$; the compounds of interest were injected onto the head of a $50 \mathrm{~m}$ HP- 624 column, and analyzed on a Shimadzu GC instrument (Greenberg et al., 1994), using a PTR-MS instrument as detector. The instrument was operated in multiple ion mode. The GC temperature was held at $0^{\circ} \mathrm{C}$ for 2 min after injection and subsequently ramped up to $200^{\circ} \mathrm{C}$ at $10^{\circ} \mathrm{C} \mathrm{min}^{-1}$. Identification of volatiles was based on a combination of retention times and selected VOC fragmentation data in the PTR-MS instrument operated in multiple ion detection (MID) mode. Retention times were obtained individually by injecting pure standards of all compounds reported in this manuscript.

\subsection{FTIR}

The open path Fourier transform infrared spectrometer (OPFTIR) was positioned on the sampling platform so that the open white cell spanned the stack directly in the rising emissions stream for continuous ( $0.83 \mathrm{~s}$ resolution) scanning. The OPFTIR system (Yokelson et al., 1997) includes a MIDAC model 2500 spectrometer; a $1.6 \mathrm{~m}$ base path, open White cell; and an MCT (mercury-cadmium-telluride), $\mathrm{LN}_{2}$ cooled detector. The path length was set to $57.7 \mathrm{~m}$ and spectral resolution was $0.5 \mathrm{~cm}^{-1}$. Before each fire, we scanned for 23 min to obtain a background spectrum. For long-duration fires with slowly changing temperature and emissions, we increased the signal to noise ratio $(S / N)$ by averaging up to 40 absorbance spectra ( $\sim 30 \mathrm{~s}$ resolution). For shorter fires with larger or more rapid temperature fluctuations, averaging was limited to 7 spectra $(\sim 6$ s resolution).

The inlet of the AFTIR (airborne FTIR) had a dedicated, halocarbon-wax, coated forward facing inlet that directed ram air through a Pyrex, multipass cell. The flow through the system was high enough to exchange the air in the AFTIR cell every 2-4 s. Fast-acting flow control valves allowed the system flow to be temporarily stopped for signal averaging and improved accuracy on "grab samples."

We used classical least squares spectral analysis (Griffith, 1996) to retrieve excess mixing ratios for water $\left(\mathrm{H}_{2} \mathrm{O}\right)$, methane $\left(\mathrm{CH}_{4}\right)$, carbon monoxide, $(\mathrm{CO})$, methanol $\left(\mathrm{CH}_{3} \mathrm{OH}\right)$, ethylene $\left(\mathrm{C}_{2} \mathrm{H}_{4}\right)$, phenol $\left(\mathrm{C}_{6} \mathrm{H}_{5} \mathrm{OH}\right)$, acetone $\left(\mathrm{CH}_{3} \mathrm{C}(\mathrm{O}) \mathrm{CH}_{3}\right)$, hydroxyacetone $\left(\mathrm{CH}_{2}(\mathrm{OH}) \mathrm{C}(\mathrm{O}) \mathrm{CH}_{3}\right)$, isoprene $\left(\mathrm{C}_{5} \mathrm{H}_{8}\right)$, hydrogen cyanide $(\mathrm{HCN})$, furan $\left(\mathrm{C}_{4} \mathrm{H}_{4} \mathrm{O}\right)$, nitric oxide (NO), nitrogen dioxide $\left(\mathrm{NO}_{2}\right)$ and formaldehyde (HCHO). We used spectral subtraction (Yokelson et al., 1996) to retrieve excess mixing ratios for water 


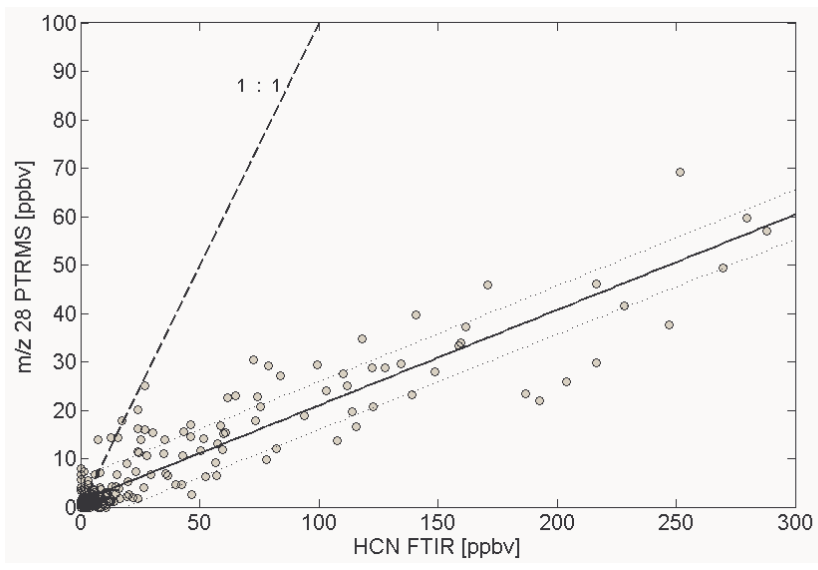

Fig. 4. HCN intercomparison plot (laboratory data). Black solid line depicts the best fitted line. Thin dotted lines indicate the $95 \%$ confidence interval and the dashed line represents the $1: 1$ line for comparison. The lower response of the PTRMS instrument is due to the backward reaction $\mathrm{HCNH}^{+}+\mathrm{H}_{2} \mathrm{O}->\mathrm{HCN}+\mathrm{H}_{3} \mathrm{O}^{+}$.

$\left(\mathrm{H}_{2} \mathrm{O}\right)$, ammonia $\left(\mathrm{NH}_{3}\right)$, formic acid $(\mathrm{HCOOH})$, acetic acid $\left(\mathrm{CH}_{3} \mathrm{COOH}\right)$, glycolaldehyde $\left(\mathrm{CH}_{2}(\mathrm{OH}) \mathrm{CHO}\right)$, acetylene $\left(\mathrm{C}_{2} \mathrm{H}_{2}\right)$, propylene $\left(\mathrm{C}_{3} \mathrm{H}_{6}\right)$, and methyl vinyl ether (MVE, $\mathrm{CH}_{3} \mathrm{OCHCH}_{2}$ ). These molecules account for all the significant, sharp (i.e. FWHM $<\sim 5 \mathrm{~cm}^{-1}$ ) features observed from $600-3400 \mathrm{~cm}^{-1}$ in the IR spectra. The detection limit for most gases was 5-20 ppbv for a $30 \mathrm{~s}$ measurement time and $\sim 10-50 \mathrm{ppbv}$ at the highest time resolution used $(6 \mathrm{~s})$. The typical uncertainty in an FTIR mixing ratio is $\pm 5 \%(1 \sigma)$ due to calibration or the detection limit $(2 \sigma)$, whichever is greater.

\subsection{Auxiliary measurements}

For laboratory experiments $\mathrm{CO}_{2}$ and $\mathrm{CO}$ in the emissions stream were monitored continuously using a LICOR 6262 and a TECO $48 \mathrm{C}$ in addition to the OP-FTIR. (A second LICOR 6262 was used to monitor background $\mathrm{CO}_{2}$ levels in the combustion chamber.) These instruments were calibrated with NIST traceable standards. In addition, stack air was drawn through a cyclone to remove particles larger than $2.5 \mu \mathrm{m}$ effective diameter, then onto Teflon filters. We continuously monitored fuel mass and stack temperature, pressure, and flow with $2 \mathrm{~s}$ resolution. The data from these instruments was coupled with PTR-MS and GC-PTR-MS data to calculate fire-integrated emission factors that are presented in Christian et al. $\left(2007 \mathrm{a}^{1}\right)$.

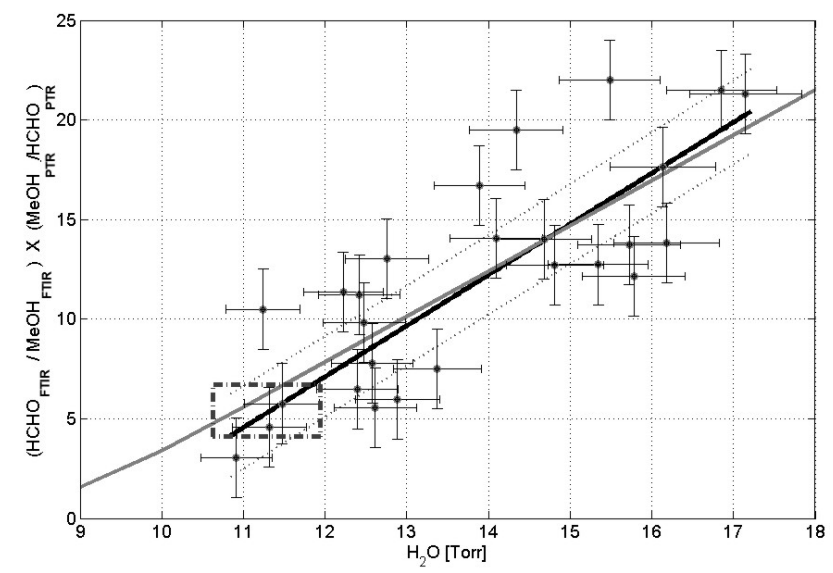

Fig. 5. HCHO ratios between PTRMS (PTR) and FTIR (FTIR) plotted versus ambient water concentration (field data). The solid gray line is a fitted line according to (Hansel et al., 1997), yielding a backward reaction rate constant of $\mathrm{k}_{b}=3 \times 10^{-10} \mathrm{~cm}^{3} / \mathrm{s}$. The solid black line is a linear line fitted through the data points $\left[f(x)=2.55( \pm 0.63) * x-23.54( \pm 8.7) ; R^{2}: 0.73\right]$. Thin dotted lines correspond to the $1 \sigma$-levels of this fit $(25 \%)$. The dashed rectangle indicates conditions during laboratory measurements.

\section{Results and discussion}

3.1 Laboratory fires: identification and intercomparison of VOCs measured by PTR-MS and FTIR

This section reports an improved evaluation and intercomparison of the PTR-MS instrument using a two-pronged approach. Following work published by Christian et al. (2004) we report PTRMS/FTIR ratios for all species where an intercomparison between these two instruments is possible. Whenever possible a comparison between the PTR-MS and FTIR instrument will be presented as a ratio (PTR-MS/FTIR) inferred from the slope of an $\mathrm{x}-\mathrm{y}$ weighted (orthogonal) regression. In addition we used a GC-PTR-MS setup to assess the specificity of individual PTR-MS mass channels (Table 1). Figure 2 shows typical chromatograms obtained by coupling the PTR-MS to a GC column. In this paper, we compute two separate averages, (1) for all the data obtained from the laboratory tropical-fuel fires and (2) for all the fires measured in the field. We report an average emission ratio to acetonitrile for each VOC for both experiments (Table 2). Species listed in Tables 1, 2 and 3 accounted for $72 \pm 4 \%$ of the total response observed on all PTR-MS mass channels $\left(\mathrm{m} / \mathrm{z} 18^{+}\right.$to $\left.\mathrm{m} / \mathrm{z}, 205^{+}\right)$.

\subsubsection{VOCs containing nitrogen:}

Ammonia $\left(\mathrm{m} / \mathrm{z}, 18^{+}\right)$: The detection limit of the PTR-MS for ammonia for a $1 \mathrm{~s}$ integration time was on the order of $5 \mathrm{ppbv}$ during this study. The ability to detect ammonia with the PTR-MS instrument has improved considerably compared to 
an earlier study (Christian et al., 2004) by using a heated silica steel capillary $\left(60^{\circ} \mathrm{C}\right)$ as a sample inlet. We tested the response time by spiking ammonia to the air flowing through the sampling stack. At high concentrations ( $>100 \mathrm{ppbv}$ ) the rise time of ammonia in the PTRMS instrument was 5-10 s slower than in the open-path FTIR instrument. The initial decay time on $\mathrm{m} / z .18^{+}$was 13 seconds compared to $6 \mathrm{~s} \mathrm{de}-$ cay time in the smoke stack observed by the open path FTIR instrument. The remaining $14 \%$ of the initial concentration spike contaminated the PTR-MS instrument for several hours. Yokelson et al. (2003b) compared the ammonia delay time in a fast flow, closed-cell FTIR system to that of nonsticky gases and saw similar delays $(\sim 10-40 \mathrm{~s})$. Figure 3 shows an intercomparison plot between the open path FTIR and PTR-MS instrument for 3 fires with sufficiently high signal/noise ratio. The PTR-MS response time for ammonia in these experiments was longer (30-60 s) compared to the standard addition experiment described above. This is probably because passivation of surfaces can take more time at lower concentrations. An $\mathrm{x}-\mathrm{y}$ weighted regression yielded slopes of $0.69 \pm 0.04$ (fire 1, Tropical composite, circles, Rsquare: 0.988), $0.30 \pm 0.06$ (fire 2, Cacao, triangle synbols, R-square: 0.64 ) and $0.37 \pm 0.05$ (fire 3, Terminalia catappa, square symbols, R-square: 0.9197$)$, respectively. On average the PTR-MS trace was 55\% lower than the open path FTIR signal for ammonia, but this ratio is probably specific for the concentrations and flow rates that we encountered. We assume the losses occur in the inlet plumbing (air was pulled through a $\sim 2 \mathrm{~m}$ long $3 / 8^{\prime \prime}$ Teflon line). In fires with high ammonia emissions (fire 1) the losses appear to be smaller again consistent with faster passivation at higher concentrations. Our measurements suggest that further improvements of the inlet manifold (e.g. higher flow rates, higher temperatures or halocarbon wax coating) could enable the PTR-MS instrument to measure ammonia from fires in the future much better. Recently, significant improvement of ammonia measurements using the PTR-MS instrument has been achieved by using $\mathrm{O}_{2}^{+}$chemistry (Norman et al., 2007). The downside of using $\mathrm{O}_{2}^{+}$chemistry is that the analysis of VOCs based on $\mathrm{H}_{3} \mathrm{O}^{+}$chemistry is not possible anymore. For specific applications however $\mathrm{O}_{2}^{+}$chemistry could be a significant advancement for measuring ammonia in the future.

$H C N\left(\mathrm{~m} / z 28^{+}\right)$: We did not observe significant interferences on this PTR-MS mass channel. As described below for formaldehyde, the backward reaction of the protonated species $\mathrm{HCNH}^{+}$can be significant due to a very low proton affinity $(\mathrm{PA}=170.4 \mathrm{kcal} / \mathrm{mol})$, resulting in a lower and humidity dependent sensitivity. Christian et al. (2004) applied a rate constant and rough method for correcting formaldehyde mixing ratios suggested by Hansel et al. (1997) and found that the correction factor can be on the order of four. They applied the same factor to $\mathrm{HCN}$, which has the same proton affinity as formaldehyde. A factor of four for $\mathrm{HCN}$ is close for the present laboratory experiment (see Fig. 4), which yielded a PTRMS/FTIR ratio of $0.19 \pm 0.01$. While the PTRMS instrument was able to detect $\mathrm{HCN}$ on this mass channel in the field, it was not possible to measure $\mathrm{HCN}$ with the FTIR instrument in the field. We assume that a relationship similar to formaldehyde would be true for field data and correct this PTRMS mass channel based on our HCHO PTRMS/FTIR comparison in the field (see next section on oxygenated VOCs).

Acetonitrile $\left(\mathrm{m} / \mathrm{z}, 42^{+}\right)$: This compound was only measured by PTR-MS. GC-PTR-MS measurements (Fig. 2) do not show any significant interference, suggesting that charge transfer reaction between $\mathrm{O}_{2}^{+}$and alkanes is not important in smoke under standard PTR-MS operating conditions. Acetonitrile is thought to be primarily emitted from burning vegetation. Here we use it to report VOC emission ratios to acetonitrile from fires. There are several advantages of using acetonitrile as a biomass burning marker. It is very long lived ( $\tau=\sim 900 \mathrm{~d}$ ), has no significant sources other than burning vegetation, and is not produced from gas phase chemistry in the atmosphere, which for example can alter excess mixing ratios of CO (Mauzerall et al., 1998). VOC/acetonitrile ratios are useful for intercomparing different chemical datasets and detecting the influence of fires on experiments focused on other phenomena. The FTIR instrument was not able to detect acetonitrile because the reasonably strong features in the IR-spectrum are overlapped by water lines in smoke.

Propenenitrile $\left(\mathrm{m} / \mathrm{z}, 54^{+}\right)$and Propanenitrile $\left(\mathrm{m} / \mathrm{z}, 56^{+}\right)$: Both compounds have been reported in earlier laboratory studies (Christian et al., 2004; Lobert et al., 1990) and were confirmed using the GC-PTRMS setup during this work.

Pyrrole $\left(\mathrm{m} / \mathrm{z}, 68^{+}\right)$: No significant interferences for pyrrole $\left(\mathrm{C}_{4} \mathrm{H}_{5} \mathrm{~N}\right)$ have been observed in the present study.

\subsubsection{VOCs containing oxygen:}

Formaldehyde $\left(\mathrm{m} / \mathrm{z}, 31^{+}\right)$: The detection limit of the PTR-MS for formaldehyde was on the order of 2-4 ppbv during this study. The sensitivity for measuring formaldehyde with the PTR-MS is compromised by the humidity dependent backward reaction $\mathrm{k}_{b}$ (Hansel et al., 1997).

$$
\begin{aligned}
& \mathrm{H}_{3} \mathrm{O}^{+}+\mathrm{HCHO} \stackrel{k f}{\longrightarrow} \mathrm{H}_{2} \mathrm{O}+\mathrm{HCHOH}^{+} \\
& \mathrm{H}_{2} \mathrm{O}+\mathrm{HCHOH}^{+} \stackrel{k b}{\longrightarrow} \mathrm{H}_{3} \mathrm{O}^{+}+\mathrm{HCHO}
\end{aligned}
$$

Comparison with results obtained by the FTIR instrument shows that the humidity dependent correction is linear over the range investigated during this work. During laboratory experiments the correction factor calculated for formaldehyde (5.2) was similar to HCN. During field experiments the sensitivity was lower than during laboratory experiments due to higher absolute water content in the atmosphere. The humidity dependent calibration curve for the field data is shown in Fig. 5, where the FTIR/PTRMS ratios are plotted as a function of water content in the atmosphere. A theoretical 
line (according to Eq. 2) is fitted using a non-linear least squares fit (gray solid line). This fit results in a backward reaction constant of $\mathrm{k}_{b}=3 \times 10^{-10} \mathrm{~cm}^{3} / \mathrm{s}$ (the forward reaction rate constant $\mathrm{k}_{f}$ was constrained to $2 \times 10^{-9} \mathrm{~cm}^{3} / \mathrm{s}$ ). The correction factor in Fig. 5 is plotted as a function of the ambient water content. The actual drift tube water content is higher due the internal water flow through the hollow cathode, which can add up to $\sim 10^{\circ} \%$ vov water to the drift tube. Also shown is a linear $\mathrm{x} / \mathrm{y}$ weighted fit to the dataset (black line; $\mathrm{f}(\mathrm{x})=2.55( \pm 0.63)^{*} \mathrm{x}-23.54( \pm 8.7)$; R2:0.73). Similar relationships might be used in the future to calibrate the PTRMS instrument by using the 1st water cluster $\left(\mathrm{H}_{3} \mathrm{O}^{+} \mathrm{H}_{2} \mathrm{O}\right)$ as a relative measure for humidity.

Methanol $\left(\mathrm{m} / \mathrm{z} 33^{+}\right)$: The agreement for methanol between PTR-MS and FTIR instruments was excellent during this study. The average ratio between both instruments for all laboratory fires was $1.1 \pm 0.2$. Not too surprisingly, the GC-PTR-MS measurements did not show any significant interference. Christian et al. (2004) observed similarly good agreement in an earlier study of smoke. We use methanol as a key compound to relate VOC ratios measured by PTR-MS to those measured by FTIR for the datasets obtained during the airborne TROFFEE study (Yokelson et al., 2007).

Acetaldehyde $\left(\mathrm{m} / z 5^{+}\right)$: GC-PTRMS measurements suggest that this compound was uniquely monitored by the PTRMS instrument contrasting earlier studies (Warneke et al., 2003b) that observed interferences from $\mathrm{CO}_{2} \mathrm{H}^{+}$. Different operating conditions between the drift tube and detection chamber of the PTR-MS instrument, in earlier studies might have created this artifact. For reasons similar to those mentioned for acetonitrile, the FTIR instrument was not able to detect acetaldehyde in the IR spectra.

Formic Acid $\left(\mathrm{m} / z 4^{+}\right)$: The PTRMS/FTIR ratio is $0.8 \pm 0.4$. This is higher than values observed by Christian et al. (2004). We attribute this improvement to a better inlet design of the PTRMS instrument resulting in smaller losses compared to what was used in earlier studies. Interference from ethanol was minor due to the high fragmentation (up to $90 \%)$ of ethanol and low emissions.

Acrolein $(\mathrm{m} / \mathrm{z} 57)$ : On average $84 \%$ of the signal monitored on this PTR-MS mass channel was observed by GC-PTR-MS to be acrolein with minor contributions from alkenes (15\%) and MTBE (1\%). Acrolein has a relatively small IR absorption cross-section and was below the FTIR detection limit in these experiments.

Acetone and Propanal $\left(\mathrm{m} / \mathrm{z} 59^{+}\right)$: GC-PTR-MS suggests that acetone (83\%) and propanal (13\%) account for more than $90 \%$ detected on this mass channel. A minor fragment $(4 \%)$ originating from 2,3-butanedione contributed to $\mathrm{m} / \mathrm{z}$ 59\%. Christian et al. (2004) reported a minor contribution from methyl-vinyl-ether (MVE). The GC-PTR-MS measurements however do not show a significant interference from MVE in this work. The PTRMS/FTIR ratio was close to $1.3 \pm 1.0$. The scatter and uncertainty of this intercomparison is largely due to the fact that the FTIR instrument

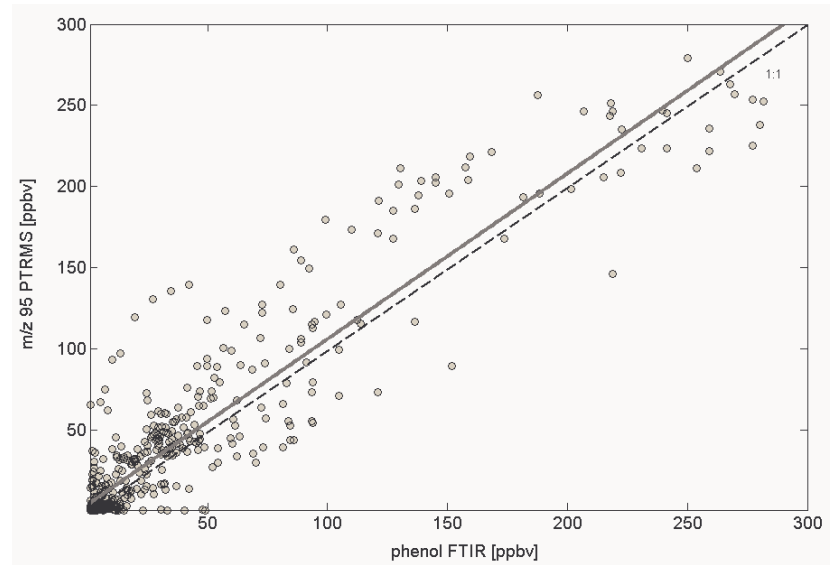

Fig. 6. Phenol intercomparison plot (laboratory data). Black solid line depicts the best fitted line and the dashed line represents the $1: 1$ line for comparison. The regression: yielded a slope of $1.02 \pm 0.15$.

was measuring close to its detection limit. Acetic Acid and Glycolaldehyde $\left(\mathrm{m} / \mathrm{z} 61^{+}\right)$: It was not possible to discriminate these structural isomers using the GC-PTR-MS interface due to insufficient trapping, losses and memory effects in the GC-inlet. However the FTIR instrument had excellent $\mathrm{S} / \mathrm{N}$ ratios for most fires and the average PTRMS/FTIR ratio for acetic acid+glycolaldehyde was $1.13 \pm 0.3$, confirming earlier results for this PTRMS mass channel (Christian et al., 2004). The acetic acid (AA)/methanol ( $\mathrm{MeOH})$ ratio was used to compare PTRMS and FTIR instruments in the field. This resulted in a $(\mathrm{AA} / \mathrm{MeOH})_{\mathrm{PTRMS}} /(\mathrm{AA} / \mathrm{MeOH})_{\mathrm{FTIR}}$ ratio of $0.73 \pm 0.4$. The average ratio by FTIR between acetic acid and glycolaldehyde for tropical fuels was $4.56 \pm 3.20(82 \%$ acetic acid and $18 \%$ glycolaldehyde). Typical fragmentation for acetic acid observed during the present study was $\mathrm{m} / \mathrm{z}$ $61^{+}: 75 \%$ and $\mathrm{m} / 243^{+}: 25 \%$. The calibration of acetic acid was based on a gravimetrically prepared liquid standard. We did not measure the fragmentation of glycolaldeyde and base the compound branching ratio on this PTRMS mass channel on results obtained from the FTIR instrument.

Isoprene and furan $\left(\mathrm{m} / \mathrm{z} 69^{+}\right)$: This PTR-MS mass channel was split on average among isoprene (48\%), furan (42\%) and minor contribution from other alkenes $(10 \%)$ as inferred from the GC-PTRMS measurements. The PTRMS $\left(\mathrm{m} / \mathrm{z} 69^{+}\right) /$FTIR (isoprene+furan) ratio also confirms the PTR-MS result since it has an average value of $1.05 \pm 0.4$. Isoprene can fragment in the PTRMS instrument and yield $\mathrm{m} / \mathrm{z} 41^{+}$. During our study the $\mathrm{m} / \mathrm{z} 69^{+}$to $\mathrm{m} / \mathrm{z} 41^{+}$ratio was $80 \%$ to $20 \%$. No fragmentation of furan was observed.

Methyl Vinyl Ketone, Methacrolein and Crotonaldehyde $\left(\mathrm{m} / \mathrm{z}, 71^{+}\right)$: These compounds have not been reported in previous studies (Andreae et al., 2001b; Christian et al., 2004). Our results show that on average all of these structural isomers contribute to $m / z 71$ as listed in Table 1 . Minor interferences $(4 \%)$ originate from higher alkenes. No comparison 
with the FTIR instrument was possible. We did not observe significant fragmentation of these compounds.

Methyl ethyl ketone (MEK) and methyl propanal $(\mathrm{m} / \mathrm{z}$ $73^{+}$): The major contribution on this PTR-MS mass channel (on average) originated from MEK (74\%) and methylpropanal (23\%) as determined with the GC interface. These compounds were below the detection limit of the FTIR instrument.

Hydroxyacetone $\left(\mathrm{m} / \mathrm{z}, 75^{+}\right)$: The PTRMS/FTIR ratio for this compound is $0.74 \pm 0.29$ similar to observations by Christian et al. (2004), who suggested that including data with low $S / N$ ratios from the FTIR instrument might cause much of this discrepancy. The fragmentation of hydroxyacetone in the PTRMS instrument was small during this study: more than $80 \%$ remained on the parent ion $(\mathrm{m} / \mathrm{z} 75)$. We detected traces of methyl acetate on this ptrms mass channel. Based on a reaction rate constant of $2.8 \times 10^{-9} \mathrm{~cm}^{3} / \mathrm{s}$ and no fragmentation (Spanel and Smith, 1998), the contribution of methylacetate would be $<3 \%$.

Methyl furans and Hexanal $\left(\mathrm{m} / \mathrm{z}, 83^{+}\right)$: According to GCPTR-MS, the two isomers 3- and 2- methyl furan contributed more than $95 \%$ to this mass channel. Hexanal dehydrates and has a major fragment $(>80 \%)$ on this mass channel, however the contribution of hexanal (2\%) was minor. We did not observe significant fragmentation of methyl furans.

2,3-Butanedione $\left(\mathrm{m} / z 8^{+}\right)$: The GC-PTR-MS data showed 2,3 butanedione as the major species $(80 \%)$ on this mass channel, with contributions from 2-pentanone (9\%) and 3-pentanone (4\%). $7 \%$ of the signal could not be identified. $34 \%$ of 2,3-butanedione showed a fragment on $\mathrm{m} / \mathrm{z} 59^{+}$(see also Fig. 2).

Substituted Furans and Furfurals $\left(\mathrm{m} / \mathrm{z}, 97^{+}\right)$: GC-PTRMS measurements showed various peaks eluting in the dimethyl - and ethyl furan region accounting for $79 \%$ of the chromatogram peak area. The remaining $21 \%$ were divided between 3-furaldehyde (20\%) and 2 furaldehyde (1\%). Friedli et al. (2001) have observed 2,4 and 2,5 methyl furan as well as 2-ethyl furans, which are likely candidates for the PTRMS signal on this mass channel. Further measurements will be necessary to fully characterize this PTR-MS mass channel.

\subsubsection{Aromatics:}

Benzene $\left(\mathrm{m} / \mathrm{z}, 79^{+}\right)$: Benzene contributed $90 \%$ to this PTRMS mass channel. Smaller amounts from the ethyl benzene fragment (10\%) were due to slightly higher collisional energies in the drift tube region used during this work than during other studies (Warneke et al., 2001).

Toluene $\left(\mathrm{m} / \mathrm{z}, 93^{+}\right)$: Toluene contributed $100 \%$ to this PTRMS mass channel within experimental uncertainty.

Phenol $\left(\mathrm{m} / \mathrm{z}, 95^{+}\right)$: The PTR-MS/FTIR intercomparison is shown in Fig. 6. The slope corresponds to a PTR-MS/FTIR ratio of 1.02. This comparison suggests that phenol is the major compound detected on this PTR-MS mass channel.

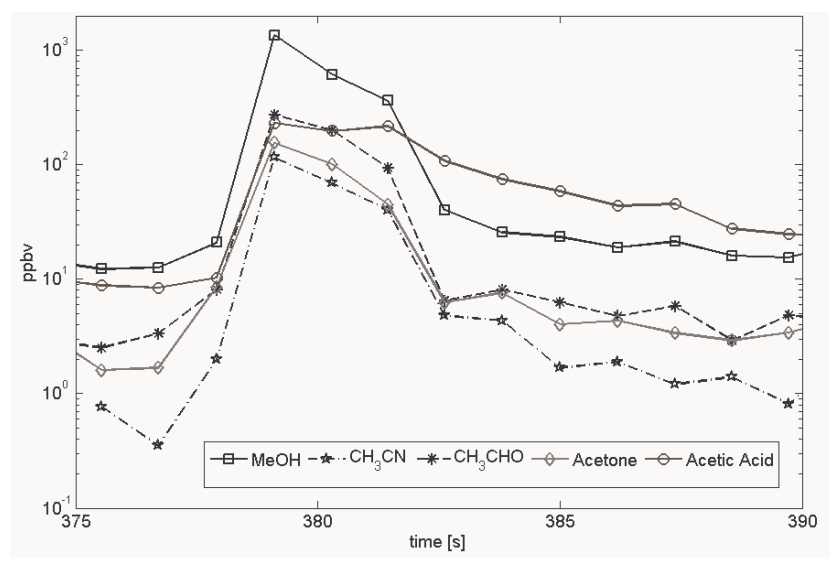

Fig. 7. Concentrations during a biomass burning plume penetration on 29 August 2004. Plotted are methanol (MeOH), acetonitrile $\left(\mathrm{CH}_{3} \mathrm{CN}\right)$, acetaldehyde $\left(\mathrm{CH}_{3} \mathrm{CHO}\right)$, acetone and acetic acid.

Phenol could not be accurately recovered using the GC-PTRMS coupling and contributed only $25 \%$ to the total signal of the GC-PTR-MS measurements. Two more peaks eluted in the GC-PTRMS chromatogram, one of which likely corresponded to vinylfuran, which is commonly observed in fires (Friedli et al., 2001) and the other remains unidentified at this point. Based on the intercomparison with FTIR, the overall bias due to interferences on this mass channel is small, part of which is likely vinyl furan.

Xylenes and Ethylbenzene $\left(\mathrm{m} / \mathrm{z}, 107^{+}\right)$: Xylenes $(\mathrm{m}, \mathrm{p}, \mathrm{o})$ account for $78 \%$ and ethylbenzene for the remaining $22 \%$ on this PTR-MS mass channel. In this study we did not see significant amounts of benzaldehyde, which would also be detected on $m / z 107^{+}$. This contrasts observations by Greenberg et al. (2006) who detected large amounts of benzaldehyde in pyrolysis experiments at low temperature $\left(<150^{\circ} \mathrm{C}\right)$. It has been previously suggested that xylenes and ethylbenzene are produced at high temperatures (e.g. $\left.>500^{\circ} \mathrm{C}\right)-$ e.g. (Browne, 1958). While some losses of benzaldehyde in our GC interface can not be entirely excluded, our measurements indicate that the production of benzaldehyde in smoldering vegetation seems small compared to the production of xylenes and ethyl benzene. Future measurements using different fuels and burning conditions will be necessary to better understand the influence of benzaldehyde on this PTRMS mass channel.

$C_{9}$ benzenes $\left(\mathrm{m} / \mathrm{z} 12 \mathrm{I}^{+}\right)$: The GC-PTRMS data show that peaks on this mass channel eluted in the region of $\mathrm{C}_{9}$ benzenes (e.g. trimethylbenezenes); we therefore attribute the signal on this PTR-MS mass channel to $\mathrm{C}_{9}$ benzenes. Possible fragmentation of higher molecular aromatics has been observed by Warneke et al. (2003a), who report that propylbenzenes can give a fragment on $\mathrm{m} / \mathrm{z} .79^{+}$(e.g. 56\%) Here we use a generic calibration that is based on 1,3,5 trimethylbenzene. No significant peaks on $m / z 79^{+}$during GC-PTR-MS 
Table 1. PTR-MS compound assignment based on GC-PTR-MS measurements $\left(^{+}\right)$and PTR-MS/FTIR intercomparison $\left({ }^{++}\right) .(\mathrm{m} / z$ : mass/charge ratio detected by PTRMS).

\begin{tabular}{|c|c|c|c|c|}
\hline $\mathrm{m} / \mathrm{z}$ & & Compounds & & \\
\hline 18 & NH3 $(100 \%)^{(++)}$ & & & \\
\hline 28 & $\mathrm{HCN}(100 \%)^{(++)}$ & & & \\
\hline 31 & Formaldehyde $(100 \%)^{(++)}$ & & & \\
\hline 33 & Methanol $(100 \%)^{(++)}$ & & & \\
\hline 42 & Acetonitrile $(100 \%)^{(+)}$ & & & \\
\hline 45 & Acetaldehyde $(100 \%)^{(+)}$ & & & \\
\hline 47 & Formic $\operatorname{Acid}^{(++)}$ & & & \\
\hline 56 & Propanenitrile $(100 \%)^{(+)}$ & & & \\
\hline 54 & Acrylonitrile $(100 \%)^{(+)}$ & & & \\
\hline 57 & Acrolein $(84 \%)^{(+)}$ & Alkenes $(15 \%)^{(+)}$ & $\operatorname{MTBE}(1 \%)^{(+)}$ & \\
\hline 59 & Acetone $(83 \%)^{(+)}$ & Propanal $(13 \%)^{(+)}$ & 2,3 Butanedione ${ }^{(+)}(4 \%)$ & \\
\hline 61 & Acetic Acid $(82 \%)^{(++)}$ & Glycolaldehyde $(18 \%)^{(++)}$ & & \\
\hline 68 & Pyrrole $(100 \%)^{(+)}$ & & & \\
\hline 69 & Isoprene $(48 \%)^{(+)}$ & Furan $(42 \%)^{(+)}$ & Other Alkenes $(10 \%)^{(+)}$ & \\
\hline 71 & $\operatorname{MVK}(48 \%)^{(+)}$ & Crotonaldehyde $(29 \%)^{(+)}$ & $\operatorname{MAC}(19 \%)^{(+)}$ & Alkenes $(4 \%)^{(+)}$ \\
\hline 73 & $\operatorname{MEK}(74 \%)^{(+)}$ & Methyl Propanal $(26 \%)^{(+)}$ & & \\
\hline 75 & Methylacetate $^{(+)}$ & Hydroxyacetone $^{(++)}$ & & \\
\hline 79 & Benzene $(90 \%)^{(+)}$ & Ethylbenzene $(10 \%)^{(+)}$ & & \\
\hline 83 & 3-Methylfuran $(84 \%)^{(+)}$ & 2-Methylfuran $(12 \%)^{(+)}$ & Hexanal $(2 \%)^{(+)}$ & residual $(2 \%)^{(+)}$ \\
\hline 87 & 2,3 Butanedione $(80 \%)^{(+)}$ & 2-Pentanone $(9 \%)^{(+)}$ & 3-Pentanone $(4 \%)^{(+)}$ & Residual $(7 \%)^{(+)}$ \\
\hline 93 & Toluene $(100 \%)^{(+)}$ & & & \\
\hline 95 & Phenol $(85 \%)^{(++)}$ & Furans $(15 \%)^{(+),(++)}$ & & \\
\hline 97 & Furans $(79 \%)^{(+)}$ & Furaldehydes $(21 \%)^{(+)}$ & & \\
\hline 107 & Xylenes $(78 \%)^{(+)}$ & Ethylbenzene $(22 \%)^{(+)}$ & & \\
\hline 121 & Trimethylbenzenes $(100 \%)^{(+)}$ & & & \\
\hline
\end{tabular}

runs suggested little contribution of propyl-benzenes, however further study is needed to characterize the abundance of different isomers on this ptrms masschannel.

\subsection{Airborne measurements}

The airborne FTIR (AFTIR) instrument sealed off and measured the contents of a cell with a 1/e exchange time of 2$3 \mathrm{~s}$ after flying thru the fire plume for 5-100 s (Yokelson et al., 2007). The PTR-MS instrument monitored individual masses sequentially with dwell times between 0.1 and $0.5 \mathrm{~s}$ while flying thru the plume. While the AFTIR sample is essentially a "grab sample" reflecting a line thru part of the plume, the PTR-MS sample is a series of point measurements that can be integrated over the whole plume. Fire plumes are normally internally well-mixed just 18 meters above the flames (Christian et al., 2004) and we assume that they are internally well-mixed at the altitudes relevant to airborne plume sampling ( $\sim 200-2000 \mathrm{~m}$ above ground): VOC ratios from the two instruments should therefore be directly comparable, which is further supported by the synthesis of the results from the different instruments (Yokelson et al., 2007).

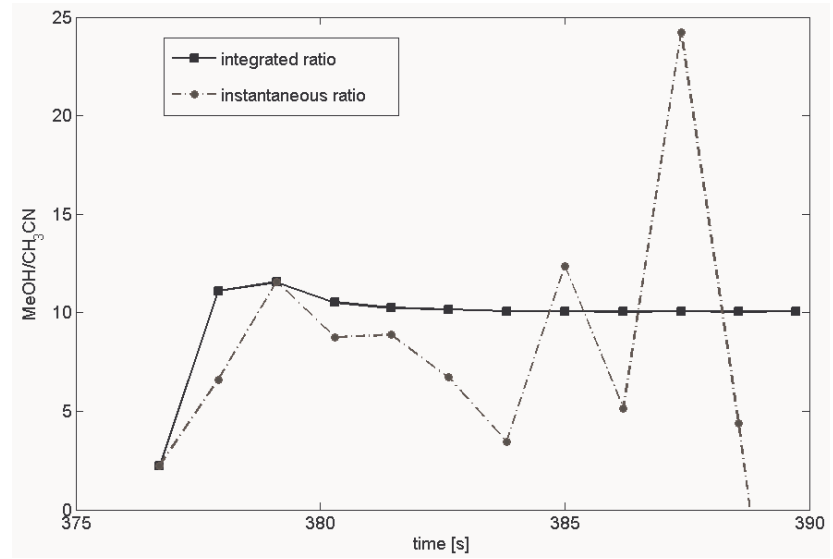

Fig. 8. Integrated and instantaneous ratio of methanol $(\mathrm{MeOH})$ and acetonitrile $\left(\mathrm{CH}_{3} \mathrm{CN}\right)$ concentration enhancements obtained from the biomass burning plume shown in Fig. 7. Best fits for methanol/acetonitrile ratios are $11.0 \pm 5.0$ (instantaneous) and $10 \pm 0.5$ (integrated). 
Figure 7 shows a typical example of a biomass burning plume penetration for selected VOCs obtained by the PTRMS instrument above a fire in Mato Grosso sampled $\sim 1500 \mathrm{~m}$ above ground on 29 August 2005. Each timestamp on the $\mathrm{x}$-axis indicates the beginning of a measurement cycle. In order to capture a plume, sampling rates greater than $1 \mathrm{~Hz}$ are desirable. The PTR-MS instrument was typically set up at these sampling rates, however in most cases more than one species was measured (e.g. up to 15), resulting in variable, sometimes longer duty cycles (e.g.'2-18 s). In order to obtain accurate emission ratios between different VOCs measured at different times, we correlated the integrated concentrations along a flight path through the smoke plume. Figure 7 also allows to asses damping effects due to sampling losses of various VOCs in the inlet line. The rise time of individual VOCs in the plume shown in Fig. 7 is very similar. Methanol mixing ratios exhibited a decline in this particular plume, which were at $10 \%$ of their peak value within 3-4 s. In comparison the acetic acid concentration reached $10 \%$ of its peak value within $\sim 7 \mathrm{~s}$. Overall this observation is confirmed by laboratory tests, showing that sampling losses in the PTR-MS inlet design are not major.

Figure 8 shows excess methanol concentrations ratioed to excess acetonitrile concentrations for the same fire on 29 August. The dash-dotted line depicts the ratios of directly measured concentrations and the solid line reflects the ratio between integrated concentrations along the flight path. In the limit the correlation of the in-situ data and the plumeintegrated data should yield the same ratio. Due to a finite duty cycle of the PTR-MS we find that the integrated emission ratios are more robust. For this particular case we obtain an emission ratio of $11.0 \pm 5.0$ for the direct (instantaneous) concentration correlation and $10 \pm 0.5$ for the integrated concentration correlation between methanol and acetonitrile. As can be seen in Fig. 8, the integrated concentration ratios decrease the uncertainty due to variable timeshifts caused by sequentially measured VOCs, measurement noise and the concentration variation in a smoke plume. The path integrated correlation also reduces the bias due to the effect of slower rise times in the sampling line which can occur for more sticky compounds such as acetic acid.

The FTIR and PTRMS datasets were combined using methanol as an internal standard since methanol is abundant and measured with high accuracy by both instruments. Because of this, we were able to calculate emission factors by the carbon mass balance method that are presented by Yokelson et al. (2007).

\subsection{Comparison of field and laboratory data}

Table 2 compares VOCs emitted by burning tropical vegetation as measured by the PTR-MS instrument under laboratory and field conditions. The values are expressed as a ratio to acetonitrile, which serves as a unique biomass burning marker. At the outset, it should be mentioned that the lab and field fires were significantly different. The laboratory fires burned mostly foliage while the field fires burned a mixture of foliage and woody material. Plants are know to concentrate their nitrogen in the leaves (Ward et al., 1996). Trunks and wood typically contain less than half as much nitrogen. Our emissions measurements suggest that the laboratory fuels had higher nitrogen content than in the field since $\mathrm{NH}_{3}$ and $\mathrm{NO}_{\mathrm{x}}$ emissions were about twice as high in the lab (Yokelson et al., 2007; Christian et al., 2007a1 $\mathrm{a}^{1}$ ). Secondly, the lab fires burned with relatively more flaming combustion as is shown by the study-average modified combustion efficiencies (MCEs) $(0.91 \pm 0.02$ for the field and $0.95 \pm 0.03$ for the lab). Despite these differences in the fires, however, on average, we get remarkable agreement between the laboratory and field VOC/acetonitrile emission ratio (ratio laboratory/field is $0.99 \pm 0.31$. In addition, the HCN/acetonitrile ratio, as measured by PTR-MS, did not differ significantly between the laboratory and field datasets (ratio laboratory/field $=0.9$ ). This is consistent with the observation of Yokelson et al. (2003a) that the HCN emission was not strongly dependent on MCE for African savanna fires. Taken together, these observations suggest that the emission factors of $\mathrm{HCN}$ and acetonitrile might be less sensitive to the nitrogen content of the burned vegetation than can be the case for the inorganic nitrogen species, such as $\mathrm{NH}_{3}$ and $\mathrm{NO}_{x}$. Some species $\left(\mathrm{m} / z 33^{+}\right.$and $\left.83^{+}\right)$listed in Table 2 show larger differences $(>1.5)$. This might partly reflect different fuel chemistry or combustion efficiencies. Table 3 shows the average emission ratio of individual species with respect to acetonitrile monitored on each PTRMS mass channel and partitioned according to the GC-PTR-MS and FTIR measurements. We used the average between emission ratios obtained in the field and laboratory as well as the field emission ratios alone for a comparison with a recent literature review by Andreae et al. (2001b). The overall averaged emission ratio for compounds investigated in this study (not including phenol) is 2.0 times higher than emission ratios for biomass burning from tropical forests recommended by Andreae et al. (2001b). Oxygenated compounds account for most of the higher average emission ratios compared to Andreae et al. (2001b); in particular the emissions of some individual compounds are significantly higher for tropical fires than values reported by Andreae et al. (2001b). Our measurements suggest that emission ratios for isoprene, acrolein, hydroxyacetone plus methylacetate, methylfurans, ethylfurans+furfural, xylenes plus ethylbenzene and phenol are higher than previously reported. In particular phenol seems to be significantly higher than values reported by Andreae et al. (2001b). The large difference for phenol could indicate analytical challenges (e.g. sampling losses, losses in cans etc.) for conventional GC-analysis used in previous studies. In summary, formaldehyde, acetic acid, methanol and acetaldehyde are among the most abundant oxygenated species emitted from tropical fires.

We found that average acetonitrile/CO ratios during this 
Table 2. PTRMS mass to charge $(\mathrm{m} / \mathrm{z}$ ) signals for all tropical laboratory fires and field data reported as a ratio (e.g. ppbv/ppbv) with respect to acetonitrile $\left(\mathrm{m} / z 42^{+}\right)$. Also listed are calibration factors (based on Eq. 1) used in this study and the method describing how these were determined.

\begin{tabular}{|c|c|c|c|c|c|}
\hline$m / z$ & Average lab & Average field & Ratio lab/field & Calibration Factor & Calibration based on \\
\hline $28^{(1)}$ & $1.8 \pm 0.5$ & $2.1 \pm 0.6$ & 0.9 & $2.8 \mathrm{e} 5$ to $1.4 \mathrm{e} 6^{(1)}$ & FTIR (HCHO) \\
\hline $31^{(1)}$ & $4.6 \pm 3.0$ & $4.5 \pm 3.7$ & 0.8 & $2.8 \mathrm{e} 5$ to $1.4 \mathrm{e} 6^{(1)}$ & FTIR (HCHO) \\
\hline 33 & $15.6 \pm 6.4$ & $9.4 \pm 5.8$ & 1.7 & $72240^{(3)}$ & Methanol \\
\hline 42 & $1.0 \pm 0.0$ & $1.0 \pm 0.0$ & 1.0 & $55800^{(3)}$ & Acetonitrile \\
\hline 45 & $4.5 \pm 1.9$ & $4.2 \pm 2.6$ & 1.1 & $60092^{(3)}$ & Acetaldehyde \\
\hline $47^{(2)}$ & $1.0 \pm 0.5$ & $1.9 \pm 1.2$ & 0.7 & $76250^{(2)}$ & FTIR \\
\hline 54 & $0.2 \pm 0.1$ & $0.4 \pm 0.1$ & 0.5 & $55800^{(3)}$ & Acetonitrile \\
\hline 57 & $2.1 \pm 0.7$ & $2.9 \pm 2.1$ & 0.7 & $51600^{(3)}$ & Acetone \\
\hline 59 & $2.1 \pm 1.2$ & $1.5 \pm 0.8$ & 1.4 & $51600^{(3)}$ & Acetone \\
\hline 61 & $8.4 \pm 5.1$ & $10.5 \pm 11.0$ & 0.8 & $60402^{(3)}$ & Acetic Acid \\
\hline 68 & $0.3 \pm 0.1$ & $0.2 \pm 0.15$ & 1.5 & $92909^{(4)}$ & $\left(\mathrm{k}_{c}=2.2 \times 10^{-9} \mathrm{~cm}^{3} / \mathrm{s}\right)$ \\
\hline 69 & $1.7 \pm 1.3$ & $1.7 \pm 1.4$ & 1.0 & $99031^{(3)}$ & Isoprene \\
\hline 71 & $1.6 \pm 1.0$ & $1.5 \pm 1.0$ & 1.0 & $63014^{(3)}$ & Methylvinylketone \\
\hline 73 & $1.8 \pm 1.7$ & $1.6 \pm 1.3$ & 1.1 & $51600^{(3)}$ & Acetone \\
\hline 75 & $2.1 \pm 1.0$ & $2.2 \pm 2.1$ & 0.9 & $92909^{(4)}$ & $\left(\mathrm{k}_{c}=2.2 \times 10^{-9} \mathrm{~cm}^{3} / \mathrm{s}\right)$ \\
\hline 79 & $0.8 \pm 0.6$ & $1.2 \pm 0.8$ & 0.7 & $92631^{(3)}$ & Benzene \\
\hline 83 & $1.8 \pm 1.9$ & $1.2 \pm 0.8$ & 1.6 & $61131^{(3)} 92909^{(4)}$ & Hexanal Furans $\left(\mathrm{k}_{c}=2.2 \times 10^{-9} \mathrm{~cm}^{3} / \mathrm{s}\right)^{(5)}$ \\
\hline 87 & $2.6 \pm 3.1$ & $1.9 \pm 1.5$ & 1.4 & $100705^{(3)}$ & 2-Pentanone \\
\hline 93 & $0.5 \pm 0.5$ & $0.7 \pm 0.5$ & 0.7 & $84000^{(3)}$ & Toluene \\
\hline 95 & $1.4 \pm 1.6$ & $1.6 \pm 1.4$ & 0.9 & $92909^{(5)}$ & $\left(\mathrm{k}_{c}=2.5 \times 10^{-9} \mathrm{~cm}^{3} / \mathrm{s}\right)^{(5)}$ \\
\hline 97 & $3.2 \pm 2.5$ & $2.4 \pm 1.8$ & 1.3 & $92909^{(4)}$ & $\left(\mathrm{k}_{c}=2.2 \times 10^{-9} \mathrm{~cm}^{3} / \mathrm{s}\right)$ \\
\hline 107 & $0.3 \pm 0.2$ & $\begin{array}{l}0.5 \pm 0.3 \\
\text { average }\end{array}$ & $\begin{array}{c}0.7 \\
0.99 \pm 0.31\end{array}$ & $78463^{(3)}$ & $\mathrm{p}+\mathrm{o}$, Xylene \\
\hline
\end{tabular}

(1) corrected using FTIR HCHO calibration: see text.

(2) corrected using FTIR calibration: see text.

(3) calibration factor based on measured standard using the compound listed in column 6.

(4) based on a default reaction rate constant $\left(\mathrm{k}_{c}\right)$ and scaled to a measured calibration factor (e.g. acetone: $\left.\left(\mathrm{k}_{c}=3.9 \times 10^{-9} \mathrm{~cm}^{3} / \mathrm{s}\right)\right)$ after correcting for possible fragmentation.

(5) same as ${ }^{(4)}$ but using a rate constant adopted from Zhao and Zhang, 2004.

study were higher for laboratory experiments (lab: $0.66 \pm 0$. $2 \%$ ) than previously published values - (e.g. (Andreae et al., 2001b): $0.25 \%$, (Christian et al., 2003): $0.12 \pm 0.09 \%$, (Holzinger et al., 1999): 0.13 $\pm 0.07 \%$, (Holzinger et al., 2005), $0.2 \%$, (Karl et al., 2003): $0.15 \pm 0.05 \%$ ). Our field measurements (0. $25 \pm 0.08 \%)$ on the other hand are lower than ratios obtained in laboratory fires. Despite the difference of acetonitrile/CO ratios between laboratory and field observations the VOC emission ratios with respect to acetonitrile (Tables 2 and 3) vary much less. In comparison the methanol/CO ratios obtained from the PTRMS instrument was $3.8 \%$ in the laboratory. Ground-based FTIR measurements of smoldering vegetation in the field exhibited a methanol/CO ratio of $4.1 \%$ (Christian et al., 2007), while airborne measurements (Yokelson et al., 2007) showed a ratio of $2.2 \%$. These values compare favorably with a recent space borne methanol/CO ratio reported to be 1.6\% (Dufour et al., 2007). Our observations could indicate that the CO emissions were more variable than VOC emissions for the particular fires investigated in this study.

\subsection{Emission ratios as a function of plume age}

Despite the inherent variability of the initial VOC/CO emission ratios from fires, there is ample evidence that photochemistry alters many VOC/CO ratios downwind (Goode et al., 2000; Hobbs et al., 2003; Jost et al., 2003). For example, Jost et al. (2003) report a 2 fold increase of acetone/CO ratios in a biomass burning plume over Namibia 2 hours downwind of the fire. These authors also measured a range between 6.6 and 20 for $1-10 \mathrm{~d}$ old plumes (ppt/ppb). Similarly, Andreae et al. (2001b) and more recently Holzinger et al. (2005) report acetone/CO ratios that are significantly enhanced in 3$10 \mathrm{~d}$ old plumes (19.5 and $18 \mathrm{ppt} / \mathrm{ppb}$ ). De Gouw et al. (2006) did not observe evidence of strong secondary production of VOCs in samples of a several days old Alaskan forest 
Table 3. Emission ratios with respect to acetonitrile (ppbv/ppbv) obtained from the TROFFEE study and compared to a recent literature review by (Andreae et al., 2001b) (AM01). Average emission ratios (column 2) are defined as the mean between laboratory and field emission ratios from Table 2. Emission factors for tropical fuels reported by AM01 were converted to emission ratios with respect to acetonitrile (ppbv/ppbv) and are listed in column 3. The last two columns depict the relative difference (ratio) between TROFFEE and AM01. avTROFFEE/AM01 (column 4) uses average emission ratios between laboratory and field measurements. fieldTROFFEE/AM01 (column 5) uses only field emission ratios obtained during the TROFFEE study.

\begin{tabular}{|c|c|c|c|c|}
\hline Compound & $\begin{array}{l}\text { TROFFEE } \\
\text { Average }\end{array}$ & AM01 & $\begin{array}{l}\text { Ratio } \\
\text { avTROFFEE/ } \\
\text { AM01 }\end{array}$ & $\begin{array}{l}\text { Ratio } \\
\text { fieldTROFFEE } \\
\text { AM01 }\end{array}$ \\
\hline Formaldehyde & 4.5 & 10.7 & 0.4 & 0.4 \\
\hline Methanol & 12.5 & 14.2 & 0.9 & 0.5 \\
\hline Acetaldehyde & 4.3 & 3.4 & 1.3 & 1.2 \\
\hline $\mathrm{HCN}$ & 2.0 & 1.2 & 1.6 & 1.8 \\
\hline Acrylonitrile & 0.3 & - & - & - \\
\hline Acrolein & 2.1 & 0.7 & 2.9 & 4.1 \\
\hline Acetone & 1.6 & 2.4 & 0.7 & 0.5 \\
\hline Propanal & 0.3 & 0.3 & 1.0 & 0.8 \\
\hline Formic Acid & 1.5 & 5.4 & 0.3 & 0.4 \\
\hline Acetic Acid* & 7.8 & 8.0 & 1.0 & 1.2 \\
\hline Glycolaldehyde* & 1.7 & - & - & - \\
\hline Pyrrole & 0.25 & - & - & - \\
\hline Isoprene & 0.8 & 0.1 & 8.0 & 8.0 \\
\hline Furan & 0.5 & 1.6 & 0.3 & 0.3 \\
\hline MVK & 0.7 & - & - & - \\
\hline MAC & 0.3 & - & - & - \\
\hline Crotonaldehyde & 0.4 & - & - & - \\
\hline MEK & 1.2 & 1.4 & 0.9 & 0.8 \\
\hline Methylacetate+Hydroxyacetone & 0.4 & 0.3 & 1.4 & 1.3 \\
\hline 3-Methylfuran & 1.2 & 0.5 & 2.7 & 1.7 \\
\hline 2-Methylfuran & 0.2 & 0.1 & 2.0 & 1.3 \\
\hline 2- and 3-Furfural & 0.6 & 0.9 & 0.7 & 0.5 \\
\hline $\mathrm{C}_{2}$-Furans & 2.2 & 0.5 & 4.7 & 3.6 \\
\hline Hexanal & 0.1 & 0.1 & 1.0 & 0.6 \\
\hline 2,3 Butanedione & 1.8 & 2.4 & 0.7 & 0.5 \\
\hline 2-Pentanone & 0.2 & 0.05 & 4.2 & 3.0 \\
\hline 3-Pentanone & 0.1 & 0.05 & 2.1 & 1.5 \\
\hline Benzene & 0.9 & 1.2 & 0.8 & 1.1 \\
\hline Toluene & 0.6 & 0.6 & 1.0 & 1.4 \\
\hline Phenol & 1.3 & 0.014 & 77.7 & 86.3 \\
\hline Xylenes & 0.3 & 0.1 & 2.6 & 3.7 \\
\hline Ethylbenzene & 0.1 & 0.04 & 2.6 & 3.7 \\
\hline \multirow{2}{*}{ MTBE } & 0.03 & - & - & - \\
\hline & & Average: & $2.0^{* *}$ & $1.9^{* *}$ \\
\hline
\end{tabular}

* acetic acid/glycolaldehyde ratio based on FTIR data

** excluding phenol

fire plume based on VOC/CO ratios. This could have been partly due to the fact that significant secondary production occurs within a couple of hours after emission (Jost et al., 2003). Any VOC/CO enhancement observed further downwind could be hard to detect without knowing the primary emission ratios from the fire, which can vary significantly depending on fuel type and temporal evolution of the fire.
Due to concentrated, regional biomass burning haze during this study we were not able to follow individual plumes for more than $\sim 20 \mathrm{~min}$, making it difficult to see significant changes in VOC ratios in specific plumes. However we can divide our dataset into 3 rough "smoke-age" categories. The laboratory measurements $(L M)$ captured smoke $\sim 10 \mathrm{~s}$ after the release. During plume penetrations $(P P)$ in the field we sampled the smoke composition several minutes 
( e.g. 1-15 min) after initial production. Transit flights through regional haze layers $(H L)$ in the afternoon were expected to probe mixed age smoke with a sample average age on the order of a few hours to a day. As expected, solely on the basis of smoke age, the emission ratios listed in Table 2 based on laboratory data and data from plume penetrations in the field compared well. We compare these initial emission ratios to VOC/acetonitrile ratios measured in the aged smoke that comprised the regional haze.

Methanol: For methanol we find ratios of $15.6 \pm 6.4(L M)$, $9.4 \pm 5.8(P P)$ and $18 \pm 6(H L)$. The field data suggest that the methanol/acetonitrile ratios in the aged regional haze $(H L)$ could be almost twice as high as during plume penetrations $(P P)$. On the other hand the laboratory data $(L M)$ show that the emission ratios in fresh plumes can be almost as high as in aged air masses $(H L)$. This inherent variability of methanol emission ratios makes it difficult to prove that any effects are caused by post-emission photochemistry. Within the variability we do not see significantly altered ratios for methanol. Holzinger et al. (2005) reported an average methanol/acetonitrile ratio of 19 in an aged smoke plume in Europe, which is close to our measurements. However, our data suggest that secondary production of methanol might play a minor role on timescales investigated in the present study supporting conclusions drawn by de Gouw et al. (2006). Primary emission ratios can be quite variable and could explain some differences reported in the literature. The methanol to $\mathrm{CO}$ ratio observed in the field during TROFFEE was $2.2 \%$. A recent space-borne measurement of an aged burning plume reported a ratio of $1.6 \%$ (Dufour et al., 2007). These observations suggest that secondary production of methanol in biomass burning plumes most likely plays a minor role.

Acetaldehyde: We do not see a dramatic change of the emission ratio for acetaldehyde, which are 4.5 $\pm 1.9(L M)$, $4.2 \pm 2.6(P P)$ and $4.2 \pm 1.7(H L)$, respectively. This could be due to the fact that production and loss terms of some reactive species counter balance each other.

Acetone: The acetone/acetonitrile emission ratios obtained from the laboratory measurements and the plume penetration flights are $2.1 \pm 1.2(L M)$ and $1.5 \pm 0.8(P P)$, respectively. In haze layers we observe a slightly higher ratio of $3.0 \pm 0.8$. Biogenic emissions of acetone are typically much smaller than those of methanol (Karl et al., 2004). The 30-50\% increase of the acetone mixing ratio in aged smoke could support the idea that the production of this compound in the plume downwind can be important Trentmann et al. (2005). For comparison Jost et al., (2003) reported a lower range of the acetone/acetonitrile emission ratio (1 d old) of 3.9. This would be consistent with our observations if the smoke in regional haze had aged for about 1 day on average.

\section{Conclusions}

We investigated VOC emissions from burning vegetation using PTR-MS, FTIR and GC-PTR-MS. This combination allowed identifying $72 \%$ of all species detected by the PTRMS instrument over the whole mass range up to $205 \mathrm{amu}$. The results show that a wide range of oxygenated species (OVOC) are produced and dominate non-methane hydrocarbon (NMHC) emissions from fires (OVOC/NMHC 4:1). Among the most abundant oxygenated compounds were formaldehyde, acetaldehyde, methanol, acetone and acetic and formic acid. We also report emission ratios for compounds, such as methyl vinyl ketone, methacrolein, crotonaldehyde, pyrrole and acrylonitrile, which were previously not quantified in the field and therefore not included in comprehensive emission compilations. Polyfunctional organic compounds detected in the higher mass range but not identified are present at individually small mixing ratios. Whether their summed concentration could play a significant role in gas-phase radical chemistry or partition onto aerosols due to heterogeneous losses and contribute to secondary organic aerosol formation should be addressed in future experiments.

Acetonitrile proved to be a valuable marker for biomass burning and was used to normalize VOC emissions from fires. The amount of acetonitrile generated from burning vegetation in these experiments apparently did not depend on the nitrogen content of the fuel. The study average acetonitrile/CO ratios were $0.66 \pm 0.20 \%$ for the laboratory and $0.25 \pm 0.08 \%$ for the field measurements during TROFFEE

Analysis of VOC ratios under laboratory, plume and haze conditions was consistent with production of some species such as acetone due to secondary chemistry in an aging plume, which needs to be taken into account for regional and global modeling exercises.

The combination of laboratory and field measurements has proven an effective way to quantify the amount and fate of biomass burning emissions.

Acknowledgements. The authors thank our pilot P. Celso and J. Carvalho, E. Alvarado, J. C. dos Santos and G. Nishioka for excellent logistical support in Brazil. We also want to thank M. Potosnak for his valuable expertise in providing an automation code for the GC-PTR-MS interface and C. Grayless and T. Lemieux (University of Colorado) for providing branches from various tropical tree species. The planned fire and airborne research was supported largely by NSF grant ATM0228003. The National Center for Atmospheric Research is sponsored by the National Science Foundation.

Edited by: R. Volkamer 


\section{References}

Andreae, M., Talbot, R., Andreae, T. and Harris, R.: Formic and acetic acid over the central Amazon region, Brazil, 1. Dry season, J. Geophys. Res., 93, 1616-1624, 1988.

Andreae, M. O., Artaxo, P., Fischer, H., Freitas, S. R., Gregoire, J. M., Hansel, A., Hoor, P., Kormann, R., Krejci, R., Lange, L., Lelieveld, J., Lindinger, W., Longo, K., Peters, W., de Reus, M., Scheeren, B., Dias, M. A. F. S., Strom, J., van Velthoven, P. F. J., and Williams, J.: Transport of biomass burning smoke to the upper troposphere by deep convection in the equatorial region, Geophys. Res. Lett., 28, 951-954, 2001a.

Andreae, M. O. and Merlet, P.: Emission of trace gases and aerosols from biomass burning, Global Biogeochem. Cy., 15, 955-966, $2001 \mathrm{~b}$.

Bertschi, I. T., Yokelson, R. J., Ward, D. E., Christian, T. J., and Hao, W. M.: Trace gas emissions from the production and use of domestic biofuels in Zambia measured by open-path Fourier transform infrared spectroscopy, J. Geophys Res., 108, 8469, doi:10.1029/2002JD002158, 2003.

Blake, N. J., Blake, D. R., Sive, B. C., Chen, T. Y., Rowland, F. S., Collins, J. E., Sachse, G. W., and Anderson, B. E.: Biomass burning emissions and vertical distribution of atmospheric methyl halides and other reduced carbon gases in the South Atlantic region, J. Geophys. Res.-Atmos., 101, 24 151-24 164, 1996.

Carvalho, J. A., Costa, F. S., Veras, C. A. G., Sandberg, E. C., Alvarado, E. C., Gielow, R., Serra, A. M., and Santos, J. C.: Biomass fire consuption and carbon release rates of rainforestclearing experiments conducted in northern Mato Grosso, Brazil, J. Geophys. Res., 106, 17 877-17 887, 2001.

Christian, T. J., Kleiss, B., Yokelson, R. J., Holzinger, R., Crutzen, P. J., Hao, W. M., Saharjo, B. H., and Ward, D. E.: Comprehensive laboratory measurements of biomass-burning emissions: 1 . Emissions from Indonesian, African, and other fuels, J. Geophys. Res.-Atmos., 108, 4719, doi:10.1029/2003JD003704, 2003.

Christian, T. J., Kleiss, B., Yokelson, R. J., Holzinger, R., Crutzen, P. J., Hao, W. M., Shirai, T. and Blake, D. R.: Comprehensive laboratory measurements of biomass-burning emissions, in : First intercomparison of open-path FTIR, PTR-MS, and GC- MS/FID/ECD, J. Geophys. Res.-Atmos., 109, D02311, doi:10.1029/2003JD003874, 2004.

Crutzen, P. J. and Andreae, M. O.: Biomass Burning in the Tropics: impact on atmospheric chemistry and biogeochemical cycles, Science, 250, 1669-1678, 1990.

Crutzen, P. J., Delany, A. C., Greenberg, J., Haagenson, P., Heidt, L. E., Lueb, R., Pollock, W., Seiler, W., Wartburg, A., and Zimmerman, P.: Tropospheric Chemical Composition Measurements in Brazil During the Dry Season, J. Atmos. Chem., 2, 233-256, 1985.

de Gouw, J. A., Warneke, C., Stohl, A., Wollny, A. G., Brock, C. A., Cooper, O. R., Holloway, J. S., Trainer, M., Fehsenfeld, F. C., Atlas, E. L., Donnelly, S. G., Stroud, V., and Lueb, A.: Volatile organic compounds composition of merged and aged forest fire plumes from Alaska and western Canada, J. Geophys. Res.-Atmos., 111, D10303, doi:10.1029/2005JD006175, 2006.

de Gouw, J. A. and Warneke, C.: Measurements of volatile organic compounds in the earths atmosphere using proton-transferreaction mass spectrometry, Mass Spectrom. Rev., 26(2), 223257, 2007.

Dufour, G., Boone, C. D., Rinsland, C. P., and Bernath, P. F.:
First space-borne measurements of methanol inside aged tropical biomass burning plumes using the ACE-FTS instrument, Atmos. Chem. Phys. Discuss., 6, 3945-3963, 2006, http://www.atmos-chem-phys-discuss.net/6/3945/2006/.

Ferek, R. J., Reid, J. S., Hobbs, P. V., Blake, D. R. and Liousse, C.: Emission factors of hydrocarbons, halocarbons, trace gases and particles from biomass burning in Brazil, J. Geophys. Res.Atmos., 103, 32 107-32 118, 1998.

Friedli, H. R., Atlas, E., Stroud, V. R., Giovanni, L., Campos, T., and Radke, L. F.: Volatile organic trace gases emitted from North American wildfires, Global Biogeochem. Cy., 15, 435452, 2001.

Goode, J. G., Yokelson, R. J., Ward, D. E., Susott, R. A., Babbitt, R. E., Davies, M. A., and Hao, W. M.: Measurements of excess $\mathrm{O}_{3}$, $\mathrm{CO}_{2}, \mathrm{CO}, \mathrm{CH}_{4}, \mathrm{C}_{2} \mathrm{H}_{2}, \mathrm{HCN}, \mathrm{NO}, \mathrm{NH}_{3}, \mathrm{HCOOH}, \mathrm{CH}_{3} \mathrm{COOH}$, $\mathrm{HCHO}$, and $\mathrm{CH}_{3} \mathrm{OH}$ in 1997 Alaskan biomass burning plumes by airborne Fourier transform infrared spctroscopy (AFTIR), J. Geophys. Res., 105, 22 147-122 166, 2000.

Greenberg, J., Lee, B., Helmig, D., and Zimmerman, P.: Fully automated gas chromatograph-flame ionization detector system for the in situ determination of atmospheric non-methane hydrocarbons at low parts per trillion concentration, J. Chromotogr., 676, 389-398, 1994.

Greenberg, J. P., Friedli, H., Guenther, A. B., Hanson, D., Harley, P., and Karl, T.: Volatile organic emissions from the distillation and pyrolysis of vegetation, Atmos. Chem. Phys., 6, 81-91, 2006, http://www.atmos-chem-phys.net/6/81/2006/.

Griffith, D. W. T.: Synthetic calibration and quantitative analysis of gas-phase FT-IR spectra, Applied Spectroscopy, 50, 59-70, 1996.

Hansel, A., Singer, W., Wisthaler, A., Schwarzmann, M., and Lindinger, W.: Energy dependencies of the proton transfer reactions $\mathrm{H}_{3} \mathrm{O}^{+}+\mathrm{CH}_{2} \mathrm{O}$ double left right arrow $\mathrm{CH}_{2} \mathrm{OH}^{+}+\mathrm{H} 2 \mathrm{O}$, Int. J. Mass Spectrom., 167, 697-703, 1997.

Hobbs, P. V., Sinah, P., Yokelson, R. J., Christian, T. J., Blake, D. R., Gao, S., Kirchstetter, T. W., Novakov, T., and Pilewskie, P.: Evolution of gases and particles from a savanna fire in South Africa, J. Geophys. Res., 108, 8485, doi:8410.1029/2002JD002352, 2003.

Holzinger, R., Warneke, C., Hansel, A., Jordan, A., Lindinger, W., Scharffe, D. H., Schade, G., and Crutzen, P. J.: Biomass burning as a source of formaldehyde, acetaldehyde, methanol, acetone, acetonitrile, and hydrogen cyanide, Geophys. Res. Lett., 26, 1161-1164, 1999.

Holzinger, R., Williams, J., Salisbury, G., Klupfel, T., de Reus, M., Traub, M., Crutzen, P. J., and Lelieveld, J.: Oxygenated compounds in aged biomass burning plumes over the Eastern Mediterranean: evidence for strong secondary production of methanol and acetone, Atmos. Chem. Phys., 5, 39-46, 2005, http://www.atmos-chem-phys.net/5/39/2005/.

Jost, C., Trentmann, J., Sprung, D., Andreae, M. O., McQuaid, J. B., and Barjat, H.: Trace gas chemistry in a young biomass burning plume over Namibia: Observations and model simulations, J. Geophys. Res., 108, 8482, doi: 8410.1029/2002JD002431, 2003.

Karl, T., Guenther, A., Spirig, C., Hansel, A., and Fall, R.: Seasonal variation of biogenic VOC emissions above a mixed hardwood forest in northern Michigan, Geophys. Res. Lett., 31, 2186-2188, 2004. 
Karl, T., Hansel, A., Mark, T., Lindinger, W., and Hoffmann, D.: Trace gas monitoring at the Mauna Loa Baseline observatory using proton-transfer reaction mass spectrometry, Int. J. Mass Spectrom., 223, 527-538, 2003.

Kaufman, Y. J., Hobbs, P. V., Kirchhoff, V. W. J. H., Artaxo, P., Remer, L. A., Holben, B. N., King, M. D., Ward, D. E., Prins, E. M., Longo, K. M., Mattos, L. F., Nobre, C. A., Spinhirne, J. D., Ji, Q., Thompson, A. M., Gleason, J. F., Christopher, S. A., and Tsay, S. C.: Smoke, Clouds, and Radiation - Brazil (SCAR-B) experiment, J. Geophys. Res.-Atmos., 103, 31 783-31 808, 1998.

Koppmann, R., Khedim, A., Rudolph, J., Poppe, D., Andreae, M. O., Helas, G., Welling, M., and Zenker, T.: Emissions of organic trace gases from savanna fires in southern Africa during the 1992 Southern African Fire Atmosphere Research Initiative and their impact on the formation of tropospheric ozone, J. Geophys. Res.Atmos., 102, 18 879-18 888, 1997.

Lindinger, W., Jordan, A., and Hansel, A.: Proton-transfer-reaction mass spectroscopy (PTR-MS): on-line monitoring of volatile organic compounds at pptv levels, Chem. Soc. Rev., 27, 347-534, 1998.

Lobert, J. M., Scharffe, D. H., Hao, W. M., and Crutzen, P. J.: Importance of biomass burning in the atmospheric budgets of nitrogen-containing gases, Nature, 346, 552-554, 1990.

Mason, S. A., Field, R. J., Yokelson, R. J., Kochivar, M. A., Tinsley, M. R., Ward, D. E., and Hao, W. M.: Complex effects arising in smoke plume simulations due to inclusion of direct emissions of oxygenated organic species from biomass combustion, J. Geophys. Res., 106, 12 527-512 537, 2001.

Mauzerall, D. L., Logan, J. A., Jacob, D. J., Anderson, B. E., Blake, D. R., Bradshaw, J. D., Heikes, B., Sachse, G. W., Singh, H., and Talbot, B.: Photochemistry in biomass burning plumes and implications for tropospheric ozone over the tropical South Atlantic, J. Geophys. Res.-Atmos., 103, 8401-8423, 1998.

McKeen, S. A., Mount, G., Eisele, F., Williams, E., Harder, J., Goldan, P., Kuster, W., Liu, S. C., Baumann, K., Tanner, D., Fried, A., Sewell, S., Cantrell, C., and Shetter, R.: Photochemical modeling of hydroxyl and its relationship to other species during the Tropospheric OH Photochemistry Experiment, J. Geophys. Res.-Atmos., 102, 6467-6493, 1997.

Norman, M., Hansel, A., and Wisthaler, A.: $\mathrm{O}_{2}^{+}$as reagent ion in the PTR-MS instrument: detection of gas-phase ammonia, Int. J. Mass Spectrom., 265(2-3), 382-387, 2007.

Roberts, J. Williams, J., Baumann, K., Buhr, M. P., Goldan, P. D, Holloway, J., Huebler, G., Kuster, W. C., McKeen, S. A., Ryerson, T.B., Trainer, M., Williams, E. J., Fehsenfeld, F. C., Bertman, S. B., Nouaime, G., Seaver, C., Grodzinsky, G., Rodgers, M., and Young, V. L: Measurements of PAN, PPN, MPAN made during the 1994 and 1995 Nashville intensives of the Southern Oxidant Study: Implications for regional ozone production from biogenic hydrocarbons, J. Geophys. Res., 103, 22 473-22 490, 1998.

Singh, H. B., Salas, L. J., Chatfield, R. B., Czech, E., Fried, A., Walega, J., Evans, M. J., Field, B. D., Jacob, D. J., Blake, D., Heikes, B., Talbot, R., Sachse, G., Crawford, J. H., Avery, M. A., Sandholm, S. and Fuelberg, H.: Analysis of the atmospheric distribution, sources, and sinksof oxygenated volatile organic chemicals based on measurements over the Pacific during TRACE-P, J. Geophys. Res., 109, D15307, doi:10.1029/2003JD003883, 2004.

Sinha, P., Hobbs, P. V., Yokelson, R. J., Bertschi, I. T., Blake,
D. R., Simpson, I. J., Gao, S., Kirchstetter, T. W., and Novakov, T.: Emissions of trace gases and particles from savanna fires in southern Africa, J. Geophys. Res., 108, 8487, doi:10.1029/2002JD002325, 2003.

Spanel P. and D. Smith: SIFT studies of the reactions of $\mathrm{H}_{3} \mathrm{O}^{+}$, $\mathrm{NO}^{+}$and $\mathrm{O}_{2}^{+}$with a series of volatile carboxylic acids and esters, Int. J. Mass Spectrom., 172, 137-147, 1998.

Trentmann, J., Yokelson, R. J., Hobbs, P. V., Winterrath, T., Christian, T. J., Andreae, M. O., and Mason, S. A.: An analysis of the chemical processes in the smoke plume from a savanna fire, J. Geophys. Res.-Atmos., 110, D12301, doi:10.1029/2004JD005628, 2005.

Ward, D. E., Hao, W. M., Susott, R. A., Babbitt, R. E., Shea, R. W., Kauffman, J. B., and Justice, C. O.: Effect of fuel composition on combustion efficiency and emission factors for African savanna ecosystems, J. Geophys. Res.-Atmos., 101, 23569 $23576,1996$.

Warneke, C., de Gouw, J. A., Goldan, P. D., Kuster, W. C., and Fall, R.: Validation of atmospheric measurements by proton-transferreaction mass spectrometry using a gas-chromatographic preseparation method, Environ. Sci. Technol., 37, 2494-2501, 2003a.

Warneke, C., De Gouw, J. A., Kuster, W. C., Goldan, P. D., and Fall, R.: Validation of atmospheric VOC measurements by proton-transfer-reaction mass spectrometry using a gaschromatographic preseparation method, Environ. Sci. Technol. 37, 2494-2501, 2003b.

Warneke, C., van der Veen, C., Luxembourg, S., de Gouw, J. A., and Kok, A.: Measurements of benzene and toluene in ambient air using proton-transfer-reaction mass spectrometry: calibration, humidity dependence, and field intercomparison, Int. J. Mass Spectrom., 207, 167-182, 2001.

Yokelson, R. J., Bertschi, I. T., Christian, T. J., Hobbs, P. V., Ward, D. E., and Hao, W. M.: Trace gas measurements in nascent, aged, and cloud-processed smoke from African savanna fires by airborne Fourier transfrom infrared spectroscopy (AFTIR), J. Geophys. Res., 108, 8478, doi:8410.1029/2002JD002322, 2003a.

Yokelson, R. J., Christian, T. J., Bertschi, I. T., and Hao, W. M.: Evaluation of adsorption effects on measurements of ammonia, acetic acid, and methanol, J. Geophys. Res.-Atmos., 108, 8478, doi:10.1029/2002JD002322, 2003b.

Yokelson, R. J., Karl, T., Artaxo, P., Blake, D., Christian, T. J., Griffith, D. W. T., Guenther, A., and Hao, W. M.: The Tropical Forest and Fire Emissions Experiment: Overview and airborne fire emission factor measurements., Atmos. Chem. Phys., 7, 51755196, 2007, http://www.atmos-chem-phys.net/7/5175/2007/.

Yokelson, R. J., Susott, R., Ward, D. E., Reardon, J., and Griffith, D. W. T.: Emissions from smoldering combustion of biomass measured by open-path Fourier transform infrared spectroscopy, J. Geophys. Res.-Atmos., 102, 18 865-18 877, 1996.

Yokelson, R. J., Susott, R., Ward, D. E., Reardon, J., and Griffith, D. W. T.: Emissions from smoldering combustion of biomass measured by open-path Fourier transform infrared spectroscopy, J. Geophys. Res.-Atmos., 102, 18 865-18 877, 1997.

Zhao, J. and R. Zhang: Proton transfer reaction rate constants between hydronium ion and volatile organic compounds, Atmos. Environ., 38, 2177-2185, 2004. 